\title{
Phytoplankton community and limnology of Chatla floodplain wetland of Barak valley, Assam, North-East India
}

\author{
H. Sultana Laskar ${ }^{(1)}$, S. Gupta ${ }^{(1), \star}$ \\ Received February 20, 2013 \\ Revised July 6, 2013 \\ Accepted July 15, 2013
}

\section{ABSTRACT}

Key-words: $\quad$ Phytoplankton diversity was investigated over a period of two years (2006 limnology, habitats, to 2008) in Chatla floodplain wetland in Barak valley, Assam, North-East phyotplankton, community, Chatla floodplain wetland India. Site 1 and site 2 are two inlets and site 3 is a lentic system associated with vegetation cover of Calamus tenuis and Baringtonia acutangula. The floodplain has a unique hydrology because of the presence of different types of habitats (inlets, fisheries, beels and outlets) which maintains a network among the floodplains, rivers and streams. Phytoplankton community composition, density and diversity were studied in relation to environmental variables. All the variables were estimated by following standard methods. Phytoplankton was collected by plankton net and quantitative estimation was made by using Sedgwick Rafter counting cell. Phytoplankton community comprised 53 taxa represented by Chlorophyceae (31), Cyanophyceae (11), Bacillariophyceae (7), Euglenophyceae (1) and Dinophyceae (3). Phytoplankton taxa was dominated by Volvox sp., Nostoc sp., Eunotia sp., Navicula sp., Euglena spp. and density was found highest in site 3 and lowest in site 1 . Shannon diversity index $\left(\mathrm{H}^{\prime}\right)$ for phytoplankton community varied between 2.4 to 2.65 indicating fairly high species diversity. The varying magnitude of correlationship among environmental variables and phytoplankton species density as shown by Canonical correspondence analysis (CCA) indicated that some of the environmental variables (water temperature, transparency, rainfall, nitrate and ammonia) are the driving factors for governing the phytoplankton species assemblages in Chatla floodplain wetland. Fluctuation of phytoplankton density and community composition in different habitats indicated various niche apportionment as well as anthropogenic influences.

\section{RÉSUMÉ}

La communauté phytoplanctonique et la limnologie de la zone humide de la plaine d'inondation Chatla dans la vallée de Barak, Assam, nord-est de l'Inde

Mots-clés :

habitats, limnologie, phytoplancton, communauté,
La diversité du phytoplancton a été étudiée sur une période de deux ans (2006 à 2008) dans la zone humide de la plaine d'inondation Chatla dans la vallée de Barak, dans l'Assam, au nord-est de l'Inde. Le site 1 et le site 2 sont deux arrivées d'eau et le site 3 est un système lentique associé à la couverture végétale de Calamus tenuis et Baringtonia acutangula. La plaine alluviale a une hydrologie unique en raison de la présence de différents types d'habitats, qui maintiennent un réseau entre les plaines inondables, les rivières et les fleuves. La composition 
plaine d'inondation Chatla de la communauté phytoplanctonique, la densité et la diversité ont été étudiées en fonction des variables d'environnement. Toutes les variables ont été estimées en suivant des méthodes standard. Le phytoplancton a été recueilli par un filet à plancton et l'estimation quantitative a été réalisée en utilisant une cellule de comptage Sedgwick Rafter. La communauté phytoplanctonique comprend 53 taxons représentés par des Chlorophyceae (31), Cyanophycées (11), Bacillariophyceae (7), Euglenophyceae (1) et Dinophyceae (3). Les taxons phytoplanctoniques sont dominés par Volvox sp., Nostoc sp., Eunotia sp., Navicula sp., Euglena sp. et la densité est la plus forte dans le site 3 et la plus faible dans le site 1. L'indice de diversité de Shannon $\left(\mathrm{H}^{\prime}\right)$ pour la communauté phytoplanctonique varie entre 2,4 à 2,65 indiquant une diversité spécifique assez grande. L'ampleur variable de la corrélation entre les variables environnementales et la densité des espèces de phytoplancton, comme indiqué par l'analyse canonique de correspondance (CCA), indique que certaines des variables environnementales (température de l'eau, la transparence, la pluie, le nitrate et l'ammoniac) sont les facteurs déterminant les assemblages d'espèces de phytoplancton dans la plaine d'inondation Chatla. La variation de la densité du phytoplancton et de la composition de la communauté dans les différents habitats indique diverses répartitions de niche ainsi que les influences anthropiques.

\section{INTRODUCTION}

Floodplain wetlands are known as biological supermarkets because of the extensive food chain and immensely rich biodiversity they support (Mitsch and Gosselink, 1993). Phytoplankton, an integral component of freshwater wetlands, lies at the base of the aquatic food web (Mustapha, 2009) and is used as an indicator of the environmental conditions of water bodies. Phytoplankton constitute the basis of the nutrient cycle in an aquatic ecosystem and play an important role in maintaining the equilibrium between living organisms and abiotic factors. The phytoplankton community on which the whole aquatic population depends is largely influenced by the interaction of a number of physicochemical factors (Hulyal and Kaliwal, 2009). The community composition in floodplain lakes is clearly related to hydrology, relevant nutritional resources and habitat characteristics, mainly via input of $\mathrm{N}$ and $\mathrm{P}$ from the eutrophic main channels during floods. The plankton species richness is related to the complexity of habitats formed by the presence of aquatic vegetation (Van den Brink et al., 1994). Phytoplankton productivity and composition are influenced by the spatial and temporal dynamics of environmental factors (Sommer, 1989) dominated by the solar energy cycle (Patterson and Wilson, 1995).

Several studies have been carried out on the diversity of the phytoplankton community in relation to limnological characteristics of different aquatic ecosystems worldwide (Nabout et al., 2005; Onyema, 2007; Branes et al. 2007; Chattopadhyay and Banerjee, 2007; Senthilkumar and Sivakumar, 2008; Nwankwo et al., 2008; Olele and Ekelemu, 2008; Chellappa et al., 2008; Borges and Train, 2009; Silva et al., 2010). However, information on the role of different habitats in determining the phytoplankton diversity of a particular aquatic ecosystem is scarce. Chatla floodplain wetland is formed by the meandering River Ghagra, a south bank tributary of River Barak of southern Assam, North-East India, and has a unique hydrology because of the presence of different types of habitats (inlets, floodplain fisheries, beels and outlets) which maintains a network among the floodplains, rivers and streams. The phytoplankton dynamics of different habitats of Chatla wetland has not yet been thoroughly investigated. A limited number of studies have been carried out on the phytoplankton community composition of Chatla floodplain (Gupta et al., 1994; Duttagupta et al., 2004; Bhuiyan and Gupta, 2007; Laskar and Gupta, 2009, 2010, 2011). Therefore, the main focus of this study is to depict the relevance of limnological characteristics and the role of different habitats in assessing the phytoplankton diversity, community composition and abundance in three different habitats of Chatla wetland. 


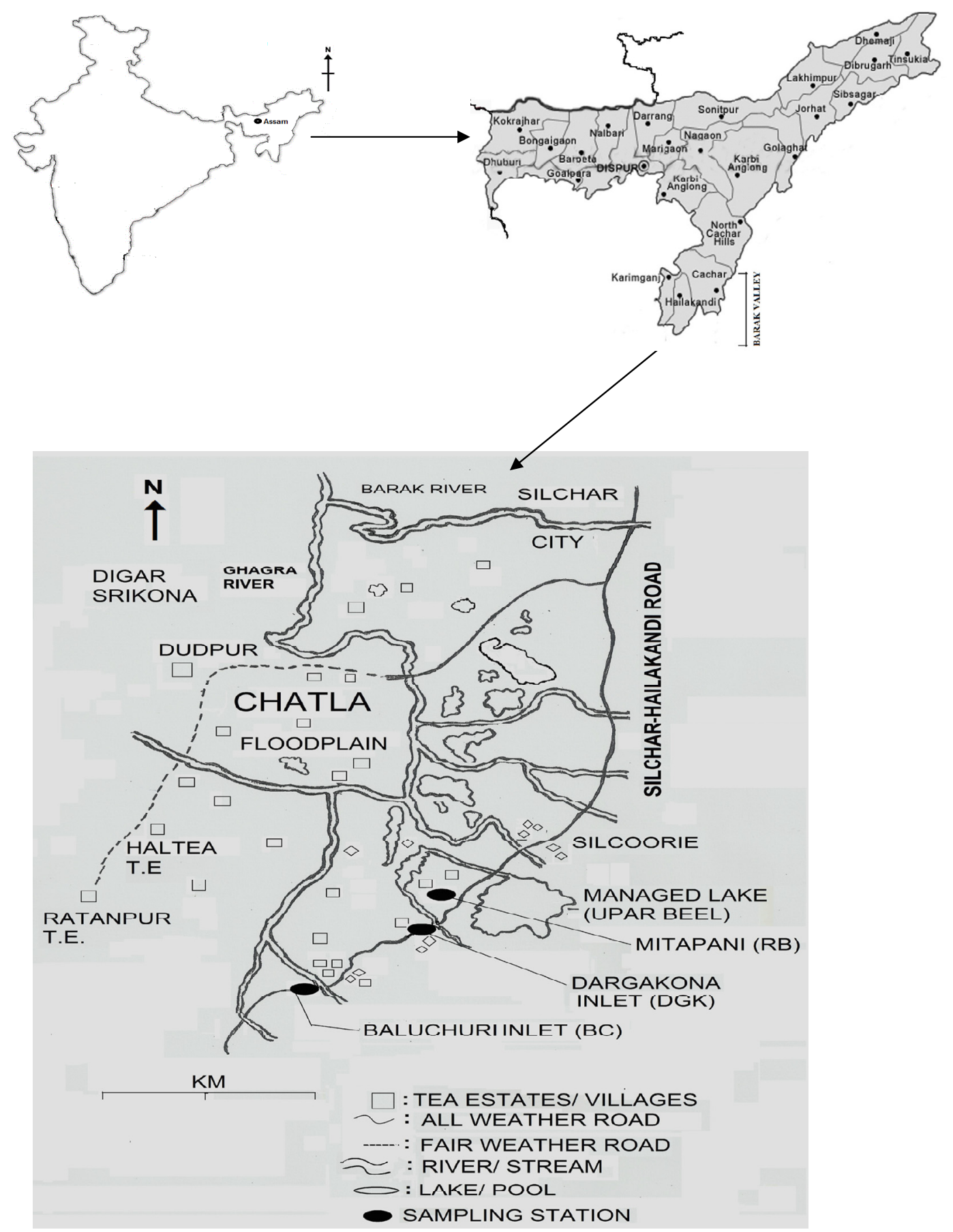

Figure 1

Map showing different sampling sites of Chatla floodplain wetland, Cachar, Assam, North-East India.

\section{MATERIALS AND METHODS}

Water samples in three replicates were collected seasonally (in PET bottles) from 3 (three) selected sampling sites of Chatla floodplain from September 2006 to August 2008 where site 1, Baluchuri (BC), and site 2, Dargakona (DGK), are lotic systems and site 3, an area with Calamus tenuis-Baringtonia acutangula associations (RB), is a lentic system (Figure 1). Surface water temperature and transparency were measured in situ by using a mercury thermometer and a Secchi disc, respectively. Turbidity was measured by a Turbidimeter (Systronics). Samples for dissolved oxygen (DO) were fixed in the field and estimated by Winkler's 
method (Winkler, 1888). Total alkalinity (TA), $\mathrm{pH}$, electrical conductivity (EC), total dissolved solids (TDS), free carbon dioxide $\left(\mathrm{FCO}_{2}\right)$, chloride content $\left(\mathrm{Cl}_{2}^{-}\right)$and biochemical oxygen demand (BOD) were measured by standard methods (APHA, 2005). Total hardness (TH) was determined by the EDTA titration method (Romesh and Anbu, 1996). Nutrients such as nitratenitrogen $\left(\mathrm{NO}_{3}^{-}\right)$, phosphate-phosphorus $\left(\mathrm{PO}_{4}^{3-}\right)$ and ammonium-nitrogen $\left(\mathrm{NH}_{4}^{+}\right)$were determined by the spectrophotometric method (Golterman et al., 1978; Michael, 1984; APHA, 2005).

For phytoplankton collection, 20 (twenty) litres of water sample in three replicates from each site was filtered through a standard plankton net (mesh size $40 \mu \mathrm{m}$ ) and preserved in $4 \%$ formaldehyde solution (Van Den Brink et al., 1992; Lund and Davies, 2000). Qualitative and quantitative estimation of phytoplankton was carried out with the help of a "Sedgwick Rafter" counting cell and identified using the standard literature (Edmondson, 1959; Anand, 1998). The phytoplankton community structure was analysed using the Shannon-Wiener Index of Diversity $\left(H^{\prime}\right)$, Margalef's species richness index $(d)$, the Evenness index $\left(J^{\prime}\right)$ and the BergerParker index of dominance $\left(D_{B P}\right)$ (Magurran, 2004). One-way analysis of variance (ANOVA) was performed using SPSS v. 12.0. CCA (Canonical correspondence analysis) was performed using CANOCO v. 4.5 .

\section{RESULTS AND DISCUSSION}

The limnological characteristics of different habitats of Chatla floodplain wetland are shown in Table I. Water temperature did not show much variation, ranging between $24.2^{\circ} \mathrm{C}-24.8^{\circ} \mathrm{C}$ (2006-2007) and $25.9{ }^{\circ} \mathrm{C}-27.45^{\circ} \mathrm{C}(2007-2008)$. Low transparency was found in 2006-2007 (range: $3.7-5.72 \mathrm{~cm}$ ), indicating high density of phytoplankton, and higher values in 2007-2008 $(10.43-18.05 \mathrm{~cm})$ indicated lower density of phytoplankton. The range of turbidity was found to be higher in 2006-2007 (19.9-23.4 NTU) than that of 2007-2008 (4.3-5.98 NTU), indicating higher abundance of phytoplankton in the previous year of study. DO concentration ranged between $3.52 \mathrm{mg} \cdot \mathrm{L}^{-1}$ and $4.98 \mathrm{mg} \cdot \mathrm{L}^{-1}(2006-2007)$ and $4.2 \mathrm{mg} \cdot \mathrm{L}^{-1}$ and $5.36 \mathrm{mg} \cdot \mathrm{L}^{-1}$ (2007-2008), with the highest mean DO concentration in site 2 (DGK) in both the cycles. This suggested that oxygen saturation increased due to thorough mixing of water due to the favourable impact of the monsoon rains (Thomaz et al., 2007) because this inlet is connected with Chatla floodplain wetland during monsoon. TA was found to be below the optimum level $\left(<50.0 \mathrm{mg} \cdot \mathrm{L}^{-1}\right)\left(30.52-40.7 \mathrm{mg} \cdot \mathrm{L}^{-1}\right.$ in $2006-2007$ and $29.3-34.4 \mathrm{mg} \cdot \mathrm{L}^{-1}$ in $2007-2008$ ) and $\mathrm{pH}$ of different sites was found to be in the range of 6.3-6.63 (slightly acidic to nearly neutral) in 2006-2007 and acidic to nearly neutral (5.7-6.43) in 2007-2008, which could be due to digging of sediment for construction of RCC bridges over the inlets. High EC values in all the sites indicated a high concentration of salts present in the water bodies. However, the range of $\mathrm{TH}$ and $\mathrm{Cl}_{2}^{-}$concentrations were well within the permissible limit, which abruptly declined in 2007-2008, suggesting wash-out during the large flood event of 2007. Similarly, $\mathrm{NO}_{3}^{-}$concentration ranged from $3.81 \mathrm{mg} \cdot \mathrm{L}^{-1}$ to $4.46 \mathrm{mg} \cdot \mathrm{L}^{-1}$ and $2.54 \mathrm{mg} \cdot \mathrm{L}^{-1}$ to $2.72 \mathrm{mg} \cdot \mathrm{L}^{-1}$ in 2006-2007 and in 2007-2008, respectively, much lower than the permissible limit $\left(45.0 \mathrm{mg} \cdot \mathrm{L}^{-1}\right)$. However, the range of $\mathrm{PO}_{4}^{3-}\left(3.14-4.18 \mathrm{mg} \cdot \mathrm{L}^{-1}\right.$ and $\left.5.45-7.15 \mathrm{mg} \cdot \mathrm{L}^{-1}\right)$ and $\mathrm{NH}_{4}^{+}\left(0.22-0.66 \mathrm{mg} \cdot \mathrm{L}^{-1}\right.$ and $\left.0.19-0.79 \mathrm{mg} \cdot \mathrm{L}^{-1}\right)$ concentrations in different habitats of Chatla wetland was found to be higher and was several times higher than the optimum value in site 1 (BC), indicating the eutrophic nature of the water body. This is further confirmed by the range of high BOD (7.67-11.68 mg. $\mathrm{L}^{-1}$ and $\left.9.51-12.68 \mathrm{mg} \cdot \mathrm{L}^{-1}\right)$ in both the cycles, suggesting high organic load due to accumulation of dead organic matter from nearby areas and increase in microbial activity.

A total of 53 phytoplankton taxa were identified belonging to Chlorophyceae (31), Cyanophyceae (11), Bacillariophyceae (7), Euglenophyceae (1) and Dinophyceae (3). Out of these, 38 and 45 taxa of phytoplankton were recorded during 2006-2007 and 2007-2008, respectively, of which site $3(\mathrm{RB})$ contributed the highest relative abundance $(44.3 \%$ and $65.6 \%$ ), followed by site 2 (DGK $-33.9 \%$ and $19.73 \%$ ). Site 1 (BC $-21.84 \%$ and $14.72 \%$ ) was the lowest contributor of phytoplankton density in both the years of study (Table II and III). 
হ̦.

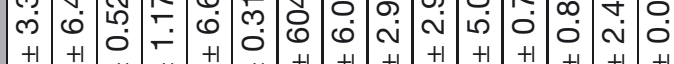

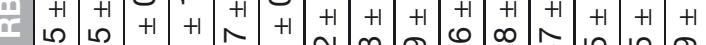
* N

ヘ

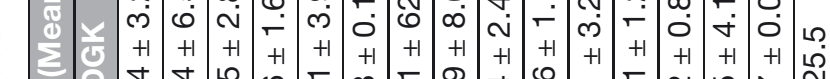

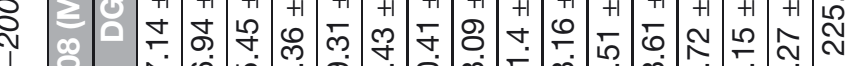

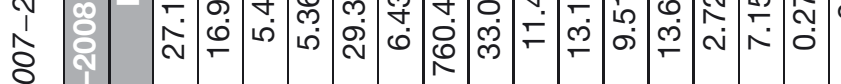

c

今

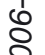

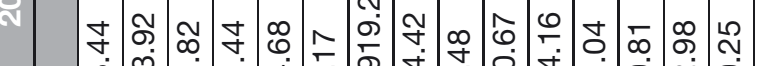

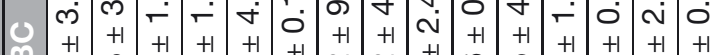

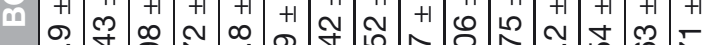

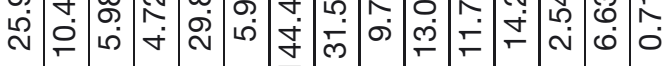

온

$\frac{0}{\frac{0}{2}}$

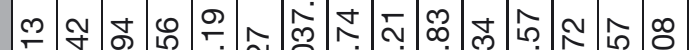

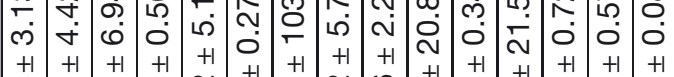

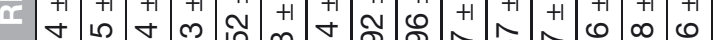
守 ৯

$\frac{\sqrt{2}}{\frac{\pi}{4}}$

4

$\stackrel{\mathbb{d}}{\mathrm{w}}$

$\frac{\pi}{d}$

离

iin

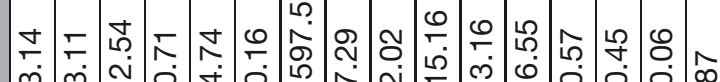

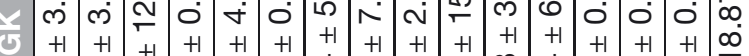

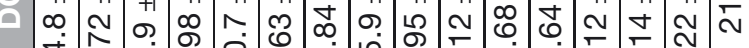

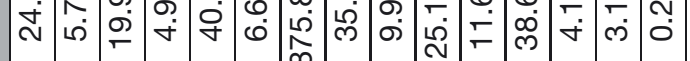
¿

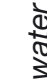

$+\frac{3}{0}$

$\stackrel{0}{5}$

ฐ

$\frac{5}{2}$

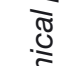

क

$\frac{\Phi}{0}$

.

$\frac{1}{\frac{1}{5}}$

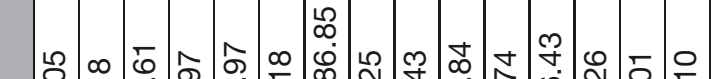

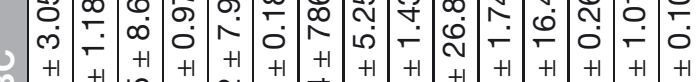

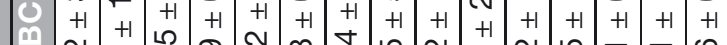

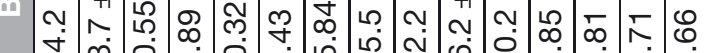
守

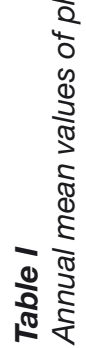

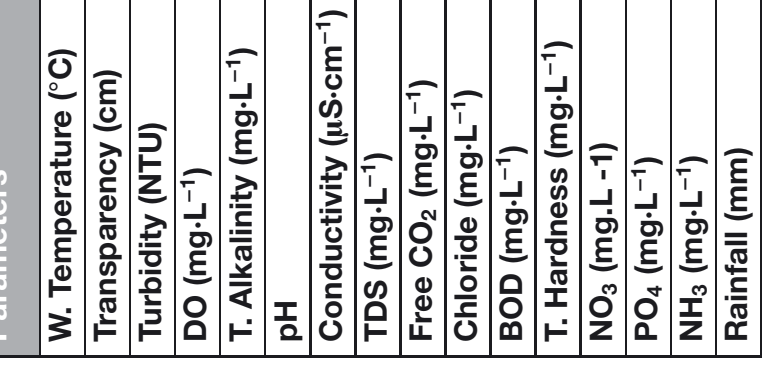




\section{Table II}

Mean density $\left(\right.$ no. $\left.\mathrm{L}^{-1} \times 10^{2}\right)$ of phytoplankton taxa recorded in Chatla floodplain during September 2006 to August 2007 (Mean \pm SE).

\begin{tabular}{|c|c|c|c|c|c|}
\hline SI. No & Genus/Species & Species code & $\overline{B C}$ & DGK & RB \\
\hline 1 & Actinastrum sp. & Acti & $0.17 \pm 0.17$ & $0.3 \pm 0.3$ & $0.94 \pm 0.65$ \\
\hline 2 & Chlorella sp. & Chlo & $0.54 \pm 0.32$ & $3.38 \pm 1.92$ & $0.69 \pm 0.36$ \\
\hline 3 & Chlamydomonas sp. & Chla & $1.16 \pm 0.42$ & $1.33 \pm 0.24$ & $0.5 \pm 0.35$ \\
\hline 4 & Cladophora sp. & Clad & $1.19 \pm 0.4$ & $0.6 \pm 0.35$ & $1.5 \pm 1.02$ \\
\hline 5 & Closterium sp. & Clos & - & - & $0.94 \pm 0.71$ \\
\hline 6 & Cosmarium sp. & Cosm & $1.07 \pm 0.09$ & $1.03 \pm 0.73$ & $1.5 \pm 0.46$ \\
\hline 7 & Cylindrocapsa sp. & Cyli & $0.47 \pm 0.47$ & $0.86 \pm 0.29$ & $0.38 \pm 0.38$ \\
\hline 8 & Desmidium sp. & Desm & $0.93 \pm 0.31$ & $0.65 \pm 0.38$ & $0.34 \pm 0.34$ \\
\hline 9 & Golenkinia sp. & Gole & $0.96 \pm 0.35$ & - & $4.44 \pm 1.3$ \\
\hline 10 & Microspora sp. & Micr & $0.67 \pm 0.38$ & $2.21 \pm 0.32$ & $1.19 \pm 0.57$ \\
\hline 11 & Maugeotia sp. & Maug & $0.34 \pm 0.34$ & $0.57 \pm 0.33$ & $3.29 \pm 1.23$ \\
\hline 12 & Spirogyra sp. & Spiro & $1.62 \pm 0.2$ & $2.13 \pm 0.43$ & $1.85 \pm 0.75$ \\
\hline 13 & S. indica & Sind & $0.55 \pm 0.34$ & $1.49 \pm 0.33$ & $1.25 \pm 0.63$ \\
\hline 14 & Sphaerozosma sp. & Spha & $0.47 \pm 0.47$ & $1.04 \pm 0.63$ & $0.75 \pm 0.47$ \\
\hline 15 & Scenedesmus quadricauda & Scen & - & $0.73 \pm 0.47$ & $0.9 \pm 0.34$ \\
\hline 16 & Triploceros sp. & Trip & $0.16 \pm 0.16$ & $0.51 \pm 0.32$ & $0.63 \pm 0.63$ \\
\hline 17 & Ulothrix sp. & Ulot & $1.26 \pm 0.55$ & $0.94 \pm 0.31$ & $0.5 \pm 0.5$ \\
\hline 18 & Volvox sp. & Volv & $1.79 \pm 0.61$ & $1.87 \pm 0.43$ & $4.4 \pm 3.66$ \\
\hline \multirow[t]{2}{*}{19} & Zygnema sp. & Zygn & $0.58 \pm 0.36$ & $1.18 \pm 0.25$ & $0.94 \pm 0.41$ \\
\hline & Chlorophyceae & & $13.93 \pm 1.1$ & $20.82 \pm 4.4$ & $26.93 \pm 11.1$ \\
\hline 20 & Anabaena sp. & Anab & $1.02 \pm 0.67$ & $2.25 \pm 0.84$ & $0.71 \pm 0.29$ \\
\hline 21 & Aulosira fertilissima & Aulo & $0.35 \pm 0.35$ & $1.19 \pm 0.08$ & $1.13 \pm 0.72$ \\
\hline 22 & Chlorococcus sp. & Ch/c & $0.59 \pm 0.35$ & $1.3 \pm 0.45$ & $1.13 \pm 1.13$ \\
\hline 23 & Lyngbya sp. & Lyng & $0.47 \pm 0.29$ & $0.5 \pm 0.29$ & $0.5 \pm 0.35$ \\
\hline 24 & Microcoleus acutissimus & Micl & $0.33 \pm 0.33$ & - & $1.06 \pm 0.21$ \\
\hline 25 & Nostoc sp. & Nost & $1.48 \pm 0.57$ & $2.72 \pm 1.19$ & $2.15 \pm 0.63$ \\
\hline 26 & Oscillatoria sp. & Oscl & $1.34 \pm 0.21$ & $0.86 \pm 0.3$ & $0.71 \pm 0.35$ \\
\hline 27 & Rivularia sp. & Rivu & - & $0.65 \pm 0.39$ & $1.1 \pm 0.52$ \\
\hline 28 & Scytonema sp. & Scyt & $1.48 \pm 0.19$ & $0.54 \pm 0.54$ & $1.56 \pm 1.0$ \\
\hline \multirow[t]{2}{*}{29} & Spirulina sp. & Spir & $0.21 \pm 0.21$ & $1.03 \pm 0.39$ & $0.5 \pm 0.35$ \\
\hline & Cyanophyceae & & $7.27 \pm 1.35$ & $11.04 \pm 1.67$ & $10.55 \pm 2.4$ \\
\hline 30 & Cymbella sp. & Cymb & $0.57 \pm 0.33$ & $1.22 \pm 0.29$ & $1.08 \pm 0.48$ \\
\hline 31 & Fragillaria sp. & Frag & $0.71 \pm 0.42$ & $0.35 \pm 0.35$ & $1.08 \pm 0.68$ \\
\hline 32 & Gyrosigma sp. & Gyro & - & $1.02 \pm 0.59$ & $0.92 \pm 0.34$ \\
\hline 33 & Navicula sp. & Navi & $1.72 \pm 0.21$ & $2.81 \pm 0.52$ & $4.0 \pm 1.35$ \\
\hline 34 & Nitzschia sp. & Nitz & $1.0 \pm 0.4$ & $1.58 \pm 0.17$ & $2.71 \pm 1.09$ \\
\hline \multirow[t]{2}{*}{35} & Synedra sp. & Synd & $1.27 \pm 0.5$ & $0.84 \pm 0.3$ & $1.42 \pm 0.28$ \\
\hline & Bacillariophyceae & & $5.27 \pm 1.21$ & $7.82 \pm 1.21$ & $11.21 \pm 3.34$ \\
\hline \multirow[t]{2}{*}{36} & Euglena sp. & Eugl & $0.31 \pm 0.31$ & $1.07 \pm 0.18$ & $4.34 \pm 0.91$ \\
\hline & Euglenophyceae & & $0.31 \pm 0.31$ & $1.07 \pm 0.18$ & $4.34 \pm 0.91$ \\
\hline 37 & Amphidinium sp. & Amph & - & $0.77 \pm 0.46$ & $0.56 \pm 0.36$ \\
\hline \multirow[t]{5}{*}{38} & Glenodinium sp. & Gleno & - & - & $0.71 \pm 0.47$ \\
\hline & Dinophyceae & & - & $0.77 \pm 0.46$ & $1.27 \pm 0.83$ \\
\hline & Total & & $26.78 \pm 2.13$ & $41.52 \pm 5.02$ & $54.3 \pm 15.18$ \\
\hline & Percentage composition (\%) & & 21.84 & 33.87 & 44.3 \\
\hline & Total No. taxa & & 32 & 34 & 38 \\
\hline
\end{tabular}

The relative abundance of different groups of phytoplankton revealed that Chlorophyceae was the most diversified and abundant group of phytoplankton, contributing around $50 \%$ of total species $(52.02 \%, 52.14 \%$ and $49.6 \%)$ in all the sites during 2006-2007 and more than $60 \%$ in sites 1 and $2(60.3 \%$ and $61.13 \%)$ during 2007-2008. In site 3 (RB) it was $37.9 \%$, followed by the Cyanophyceae and Bacillariophyceae (Figure 2). Sharma (2009) also reported Chlorophyta as the sole dominant quantitative component of phytoplankton in Loktak Lake, Manipur, India. Some authors also reported that Chlorophyceae have short life cycles and 


\section{Table III}

Mean density $\left(\right.$ no. $\left.L^{-1} \times 10^{2}\right)$ of phytoplankton taxa recorded in Chatla floodplain during September 2007 to August 2008 (Mean \pm SE).

\begin{tabular}{|c|c|c|c|c|c|}
\hline SI. No. & Genus/Species & Species code & $\mathrm{BC}$ & $\overline{D G K}$ & RB \\
\hline 1 & Actinastrum falcatus & Actn & - & - & $0.19 \pm 0.19$ \\
\hline 2 & Actidesmium Reinsh & Actd & - & $0.29 \pm 0.17$ & $0.54 \pm 0.33$ \\
\hline 3 & Apicystis sp. & Apis & $0.31 \pm 0.31$ & $0.4 \pm 0.23$ & $0.63 \pm 0.47$ \\
\hline 4 & Chara (Valliant) sp. & Char & - & - & $0.13 \pm 0.13$ \\
\hline 5 & Chlorella sp. & Chlo & $0.54 \pm 0.36$ & $0.83 \pm 0.31$ & $2.67 \pm 1.21$ \\
\hline 6 & Chlamydomonas sp. & Chla & $0.25 \pm 0.25$ & $0.34 \pm 0.2$ & $1.31 \pm 0.57$ \\
\hline 7 & Chlorococcum sp. & Chlr & - & - & $0.81 \pm 0.34$ \\
\hline 8 & Cladophora sp. & Clad & $0.63 \pm 0.63$ & & - \\
\hline 9 & Closterium sp. & Clos & - & - & $3.08 \pm 1.84$ \\
\hline 10 & Cosmarium sp. & Cosm & $0.31 \pm 0.31$ & & - \\
\hline 11 & Cylindrocystis sp. & Cyli & - & $0.17 \pm 0.17$ & $0.13 \pm 0.13$ \\
\hline 12 & Desmidium sp. & Desm & $0.31 \pm 0.31$ & $0.81 \pm 0.31$ & $0.13 \pm 0.13$ \\
\hline 13 & Microspora sp. & Micr & $1.63 \pm 0.42$ & $0.69 \pm 0.43$ & $0.25 \pm 0.25$ \\
\hline 14 & Maugeotia sp. & Maug & $0.5 \pm 0.5$ & $0.13 \pm 0.13$ & - \\
\hline 15 & Pandorina sp. & Pand & - & - & $0.31 \pm 0.31$ \\
\hline 16 & Pleodorina sp. & Pleo & - & - & $0.13 \pm 0.13$ \\
\hline 17 & Pediastrum sp. & Pedi & - & - & $0.46 \pm 0.46$ \\
\hline 18 & Spirogyra sp. & Spiro & $0.52 \pm 0.31$ & $2.79 \pm 1.72$ & $2.42 \pm 0.17$ \\
\hline 19 & S. indica & Sind & $0.25 \pm 0.25$ & & - \\
\hline 20 & Sphaerozosma sp. & Spha & - & - & $0.31 \pm 0.31$ \\
\hline 21 & Scenedesmus sp. & Scen & - & - & $0.13 \pm 0.13$ \\
\hline 22 & Schizogonium Kutzing & Schi & - & - & $0.42 \pm 0.25$ \\
\hline 23 & Schroederia sp. & Schr & - & - & $0.88 \pm 0.88$ \\
\hline 24 & Ulothrix zonata & Ulot & $0.65 \pm 0.37$ & $0.67 \pm 0.67$ & $0.63 \pm 0.24$ \\
\hline 25 & Volvox sp. & Volv & $1.79 \pm 1.79$ & $3.34 \pm 3.34$ & $6.21 \pm 1.09$ \\
\hline \multirow[t]{2}{*}{26} & Zygnema sp. & Zygn & $0.19 \pm 0.19$ & $0.25 \pm 0.25$ & $0.29 \pm 0.29$ \\
\hline & Chlorophyceae & & $7.88 \pm 1.68$ & $10.71 \pm 3.01$ & $22.06 \pm 2.54$ \\
\hline 27 & Anabaena sp. & Anab & $0.63 \pm 0.38$ & $2.0 \pm 0.84$ & $2.08 \pm 0.73$ \\
\hline 28 & Aulosira fertilissima & Aulo & - & $0.25 \pm 0.25$ & - \\
\hline 29 & Lyngbya sp. & Lyng & $0.13 \pm 0.13$ & & - \\
\hline 30 & Microcoleus sp. & Micl & - & - & $0.13 \pm 0.13$ \\
\hline 31 & Microcystis sp. & Micy & $0.5 \pm 0.5$ & & - \\
\hline 32 & Nostoc sp. & Nost & $0.42 \pm 0.42$ & $3.0 \pm 1.74$ & $2.29 \pm 0.79$ \\
\hline 33 & Oscillatoria sp. & Osci & $0.5 \pm 0.5$ & $0.31 \pm 0.31$ & $0.58 \pm 0.36$ \\
\hline 34 & Scytonema sp. & Scyt & - & - & $0.38 \pm 0.24$ \\
\hline \multirow[t]{2}{*}{35} & Spirulina sp. & Spirul & - & - & $0.58 \pm 0.34$ \\
\hline & Cyanophyceae & & $2.18 \pm 0.46$ & $5.56 \pm 2$ & $6.04 \pm 2.16$ \\
\hline 36 & Cymbella sp. & Cymb & $0.19 \pm 0.19$ & - & $0.21 \pm 0.21$ \\
\hline 37 & Eunotia sp. & Euno & - & - & $16.13 \pm 16.13$ \\
\hline 38 & Fragillaria sp. & Frag & - & - & $1.17 \pm 0.39$ \\
\hline 39 & Navicula sp. & Navi & $0.63 \pm 0.38$ & & $0.5 \pm 0.18$ \\
\hline 40 & Nitzschia sp. & Nitz & - & - & $2.04 \pm 0.36$ \\
\hline \multirow[t]{2}{*}{41} & Synedra sp. & Synd & - & - & $2.67 \pm 2.5$ \\
\hline & Bacillariophyceae & & $0.82 \pm 0.53$ & - & \begin{tabular}{|l|}
$22.72 \pm 18.93$ \\
\end{tabular} \\
\hline \multirow[t]{2}{*}{42} & Euglena sp. & Eugl & $2.0 \pm 1.31$ & $1.25 \pm 0.73$ & $6.08 \pm 2.37$ \\
\hline & Euglenophyceae & & $2.0 \pm 1.31$ & $1.25 \pm 0.73$ & $6.08 \pm 2.37$ \\
\hline 43 & Amphidinium sp. & Amph & - & - & $0.19 \pm 0.19$ \\
\hline 44 & Ceratium sp. & Cera & $0.19 \pm 0.19$ & & $0.81 \pm 0.29$ \\
\hline \multirow[t]{5}{*}{45} & Glenodinium sp. & Glen & - & - & $0.31 \pm 0.18$ \\
\hline & Dinophyceae & & $0.19 \pm 0.19$ & - & $1.31 \pm 0.94$ \\
\hline & Total & & $13.07 \pm 2.29$ & $17.52 \pm 5.26$ & $58.21 \pm 18.5$ \\
\hline & Percentage composition (\%) & & 14.72 & 19.73 & 65.6 \\
\hline & Total No. of taxa & & 22 & 17 & 38 \\
\hline
\end{tabular}




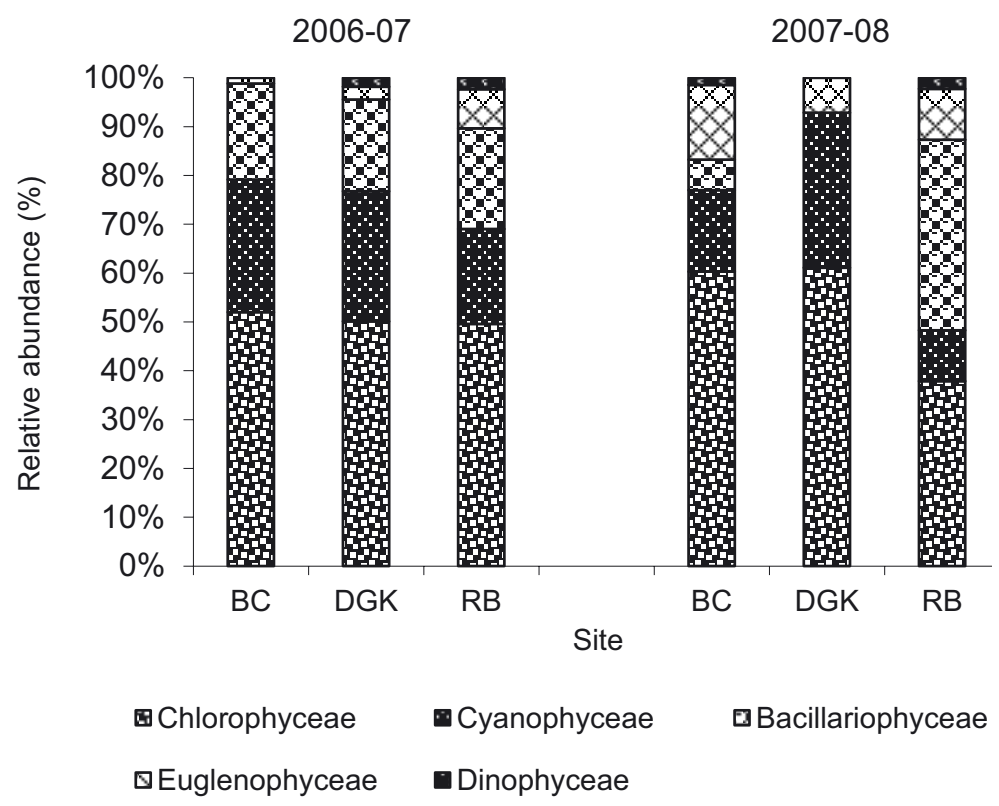

Figure 2

Relative abundance of different groups of phytoplankton community in different sites of Chatla floodplain during 2006-2007 and 2007-2008.

are opportunistic, reaching fast growth rates when nutrient availability is adjusted (HappeyWood, 1988; Vermaat, 2005). However, in site 3 (RB) Bacillariophyceae (39.03\%) dominated over Chlorophyceae (37.9\%) and Cyanophyceae (10.4\%) during 2007-2008, which could be due to the presence of vegetation cover of Calamus tennis-Baringtonia acutangula along with belts of macrophytes (Nymphaea sp., Utricularia sp. and Polygonum hydropiper) in station 3 (RB). It provided a specialised niche for various phytoplankton taxa, particularly Eunotia, the most dominant taxon. Chlorococcum sp., Closterium sp., Pediastrum sp., etc. (Tables II and III) did not occur in sites 1 and 2 during 2007-2008. Euglenophyceae dominated over Bacillariophyceae in site 1. Bacillariophyceae and Dinophyceae were totally absent in site 2 (2007-2008), while Euglenophyceae and Dinophyceae were the least abundant groups ( $<5 \%$ of total taxa) in sites 1 and 2 during 2006-2007.

Analysis of the phytoplankton community in different habitats of Chatla wetland revealed some similarities with phytoplankton studies in Calabar River, Imo River Estuary, Nigeria (Uttah et al., 2008; Akoma, 2008), where the predominance of Chlorophyceae in lotic systems with flowing water and Cyanophyceae bloom in eutrophic and polluted water was described. Laskar and Gupta (2009, 2010 and 2011) reported similar trends of phytoplankton community composition in terms of density and abundance.

The mean density of total phytoplankton in Chatla floodplain ranged from 26.78 to 54.3 no. $\mathrm{L}^{-1} \times 10^{2}$ and 13.7 to 58.21 no. $\mathrm{L}^{-1} \times 10^{2}$ during 2006-2007 and 2007-2008, respectively (Table II and III). Hulyal and Kaliwal (2009) reported that the density of total phytoplankton ranged from $110 \mathrm{org} \cdot \mathrm{L}^{-1}$ to $555 \mathrm{org} \cdot \mathrm{L}^{-1}$ in 2003 and $95 \mathrm{org} \cdot \mathrm{L}^{-1}$ to $564 \mathrm{org} \cdot \mathrm{L}^{-1}$ during 2004 in the Almatti reservoir of Bijapur District, Karnataka State, India, which was much lower than the density obtained in the present study. They suggested that the variation in phytoplankton density was influenced by temperature and $\mathrm{pH}$, as they found the maximum population in the summer season. In the present study, the maximum density of phytoplankton was influenced by temperature, along with heavy rainfall and alteration of nutrient dynamics during monsoon, because most of the phytoplankton taxa were recruited by surface runoff from nearby fisheries and other freshwater ecosystems. This agreed with the findings of Oliveira and Calheiros (2000) in a study on the south Pantanal floodplain, Brazil, where the highest phytoplankton density was recorded in the rising water period. 


\section{Table IV}

One way analysis of variance (ANOVA) for phytoplankton density and species diversity among different sites of Chatla floodplain during 2006-2007 and 2007-2008.

\begin{tabular}{|l|c|c|}
\hline Parameters & $2006-2007$ & $2007-2008$ \\
\hline Phytoplankton density & $F=6.51^{*}, p<0.004$ & $F=15.98^{* *}, p<0.000$ \\
\hline Species diversity & $F=10.72^{* *}, p<0.000$ & $F=74.03^{* *}, p<0.000$ \\
\hline
\end{tabular}

* Significant at $5 \%$ level, ${ }^{* *}$ significant at $1 \%$ level.

One-way analysis of variance (ANOVA) showed the significant site-wise variation of phytoplankton density and species diversity $(p<0.01)$ during both the years of study (Table IV). Although in site 3 species richness was found to be higher than that of the other sites with an equal no. of taxa (38) in both the years, species richness drastically declined from the previous year in sites 2 and 1 (17 and 22 taxa) during 2007-2008 (Table III). This could be linked to the disturbances caused by the construction of RCC bridges over the inlets. Further, in lentic systems, phytoplankton species diversity was always found to be higher than that of lotic systems (Rodrigues and Bicudo, 2001; Laskar, 2012).

In contrast to the highest number of taxa in site 3 in both the years, we recorded the highest values of $\mathrm{H}^{\prime}$ and $\mathrm{d}(2.65$ and 2.22) in site 2, followed by site 3 (2.52 and 2.0) during 2006-2007, while during 2007-2008 the highest values of $\mathrm{H}^{\prime}$ and $\mathrm{d}(2.17$ and 1.3) for the phytoplankton community were recorded in site 3 (RB) (Figure $3 a$ and $3 b$ ) despite its low depth ( 5-6 feet). This might be due to the fact that site 3 is located in the midst of vegetation cover of Calamus tennis-Baringtonia acutangula. According to Van den Brink et al. (1994), phytoplankton species richness is related to the complexity of habitats formed by the presence of aquatic vegetation. During 2007-2008, the relatively low values of diversity indices $(<1.5)$ and species richness (22 and 17) in sites 1 and 2 clearly indicated that disturbance caused by the construction of RCC bridges eliminated the sensitive phytoplankton such as Bacillariophyceae and Dinophyceae in site 2. Occurrence of Microcystis blooms (probably recruited during seasonal inundation) in site 1 indicated their tolerance and differential strategies for survival in polluted environmental conditions, particularly at very high concentration of $\mathrm{NH}_{4}^{+}\left(0.66 \mathrm{mg} \cdot \mathrm{L}^{-1}\right.$ and $\left.0.71 \mathrm{mg} \cdot \mathrm{L}^{-1}\right)$. Junk et al. (1989) suggested that the great diversity of habitats in floodplain systems probably allows the co-occurrence of many species with differing strategies and levels of adaptation as a result of cyclical changes caused by the flood pulse.

Figures $4 \mathrm{a}$ and $4 \mathrm{~b}$ show the CCA scores with phytoplankton species density and environment variable data for 2006-2007 and 2007-2008 in Chatla floodplain. CCA is a direct gradient analysis technique, and represents a special case of multivariate regression where species composition is directly and immediately related to measured environmental variables (Palmer, 1993). Further, CCA performs quite well with skewed species distributions, with quantitative noise in species abundance data, with samples taken from unusual sampling designs, and with highly intercorrelated environmental variables (Palmer, 1993). CCA extracts synthetic gradients from the biotic and environmental matrices, which are quantitatively represented by arrows in graphical biplots (ter Braak and Verdonschot, 1995). The length of the arrow is relative to the importance of the explanatory variable in the ordination, and arrow direction indicates positive and negative correlations (Jasprica et al., 2012).

In the present study, for the first cycle (2006-2007), the eigenvalues were 0.188 and 0.170 for axis 1 and axis 2, respectively, and the variance explained by the first two axes was $24.4 \%$. Similarly, for the second cycle (2007-2008), the eigenvalues for axis 1 and axis 2 were 0.405 and 0.324 , respectively, and the variance explained by the first two axes was $23.6 \%$. The cumulative percentage variance of species-environment relationships was 19.6 for axis 1 and 37.3 for axis 2 in the first cycle, while in the second cycle it was 19.2 and 34.5. The variance explained by the CCA in the first cycle was found to be $65.5 \%$, and for the second cycle it was $68.4 \%$. The species-environment correlations of the first two axes $(0.943$ for both in 2006-2007) and ( 0.946 and 0.899 in 2007-2008) indicated a strong relationship among all species and environmental variables, suggesting the importance of these variables 


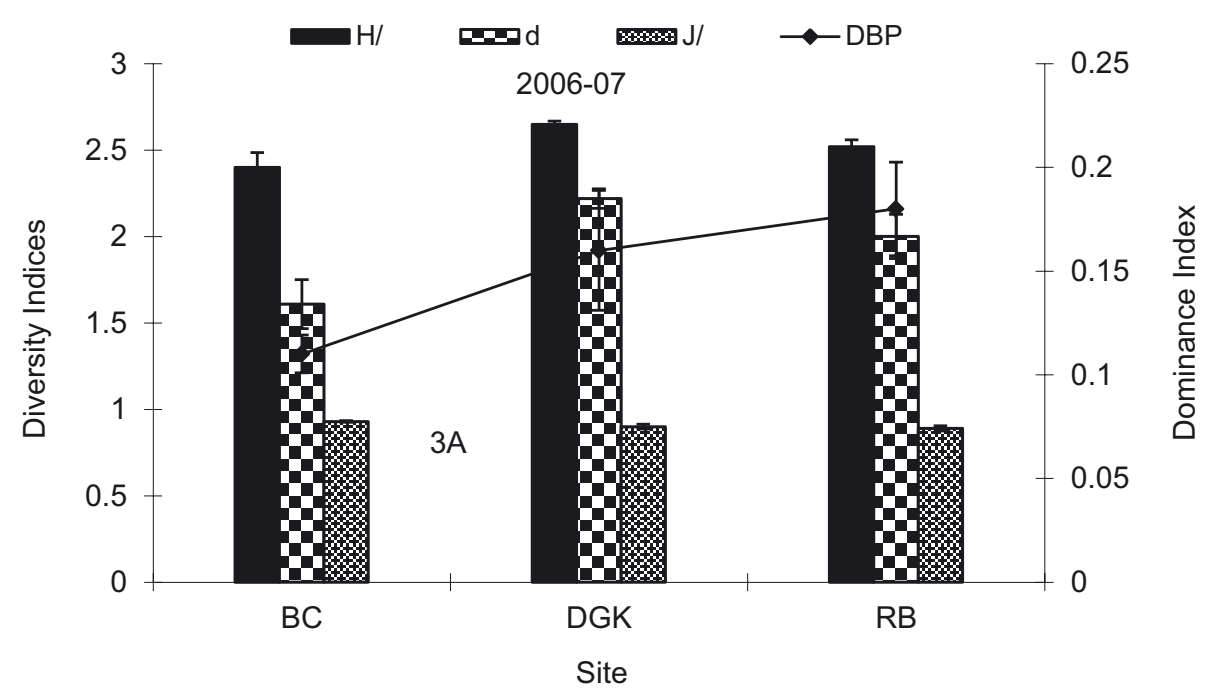

(a)

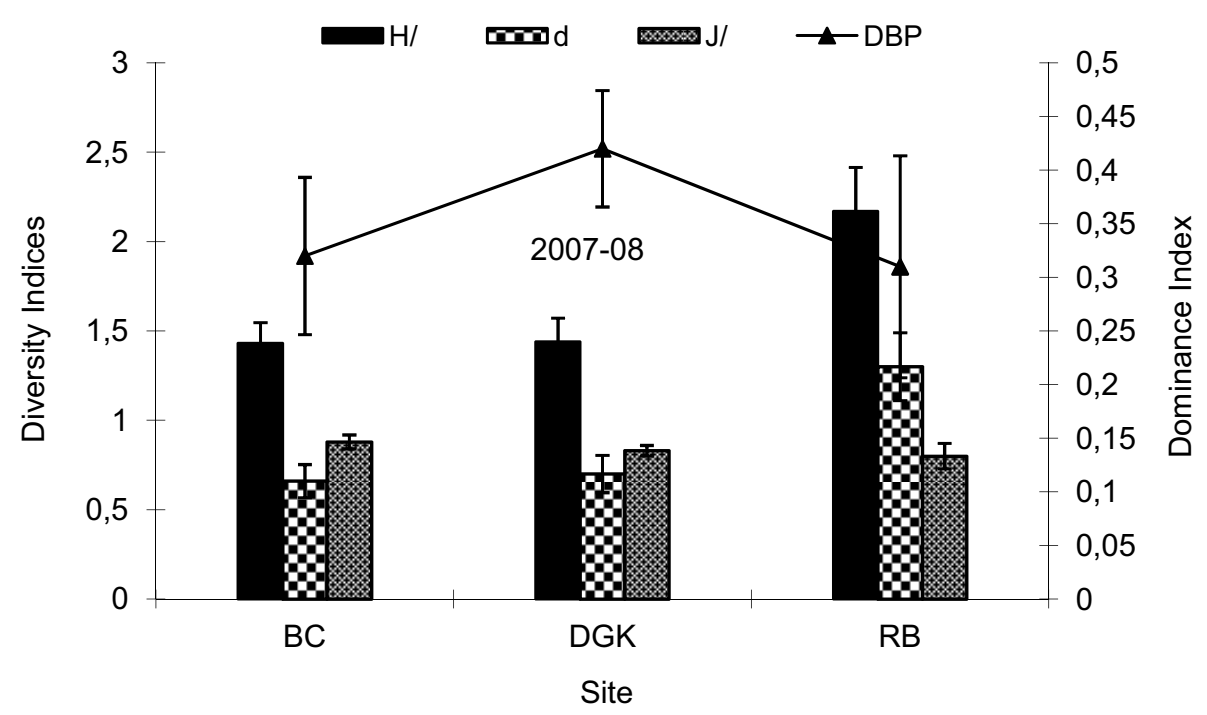

(b)

\section{Figure 3}

Seasonal variation of phytoplankton density $\left(n \circ \cdot L^{-1} \times 10^{2}\right)$ in different sites of Chatla floodplain during 2006-2007 and 2007-2008. (a) Diversity indices for phytoplankton community in different sites of Chatla floodplain during 2006-2007. (b) Diversity indices for phytoplankton community in different sites of Chatla floodplain during 2007-2008. $H^{\prime}$ = Shannon-Wiener Diversity Index, $d=$ Margalef's index of species richness, $J^{\prime}=$ Evenness Index and $D_{B P}=$ Berger-Parker Index of dominance.

in explaining plankton distribution. To evaluate the significance of the CCA axes and of the variables which defined these axes Monte Carlo tests were performed with 499 unrestricted permutations and were proved significant for both the cycles $(p<0.002$ : Table $V)$.

The CCA ordination diagram (Figures $4 a$ and 4b) revealed that during 2006-2007 both the axes were found to be highly positively correlated with TRN and WT and negatively related to TDS. Axis 1 showed a negative relationship with RF, while axis 2 was found to have a strong positive relationship with RF and TUR. Volvox was strongly influenced by TRN, Maugeotia by WT and Navicula by RF. During the second cycle (2007-2008) the importance of TRN was less pronounced, with a concomitant increase in the influence of $\mathrm{NO}_{3}$. WT showed a negative relationship with both the axes. Ulothrix, Zygnema, Navicula, Spirogyra and Oscillatoria were found to be highly positively correlated with $\mathrm{NH}_{3}$ and negatively correlated with WT. $\mathrm{NO}_{3}, \mathrm{TH}$ and $\mathrm{pH}$ showed a positive relationship with axis 2 but a negative relationship 


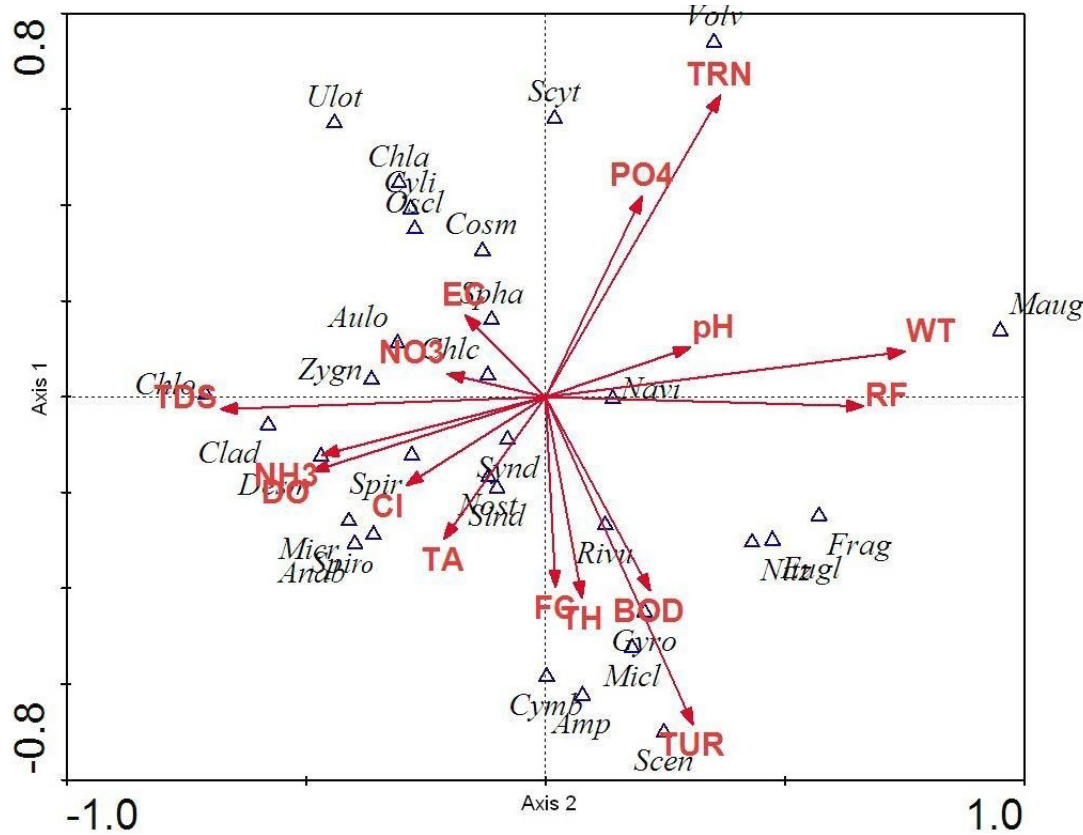

(a)

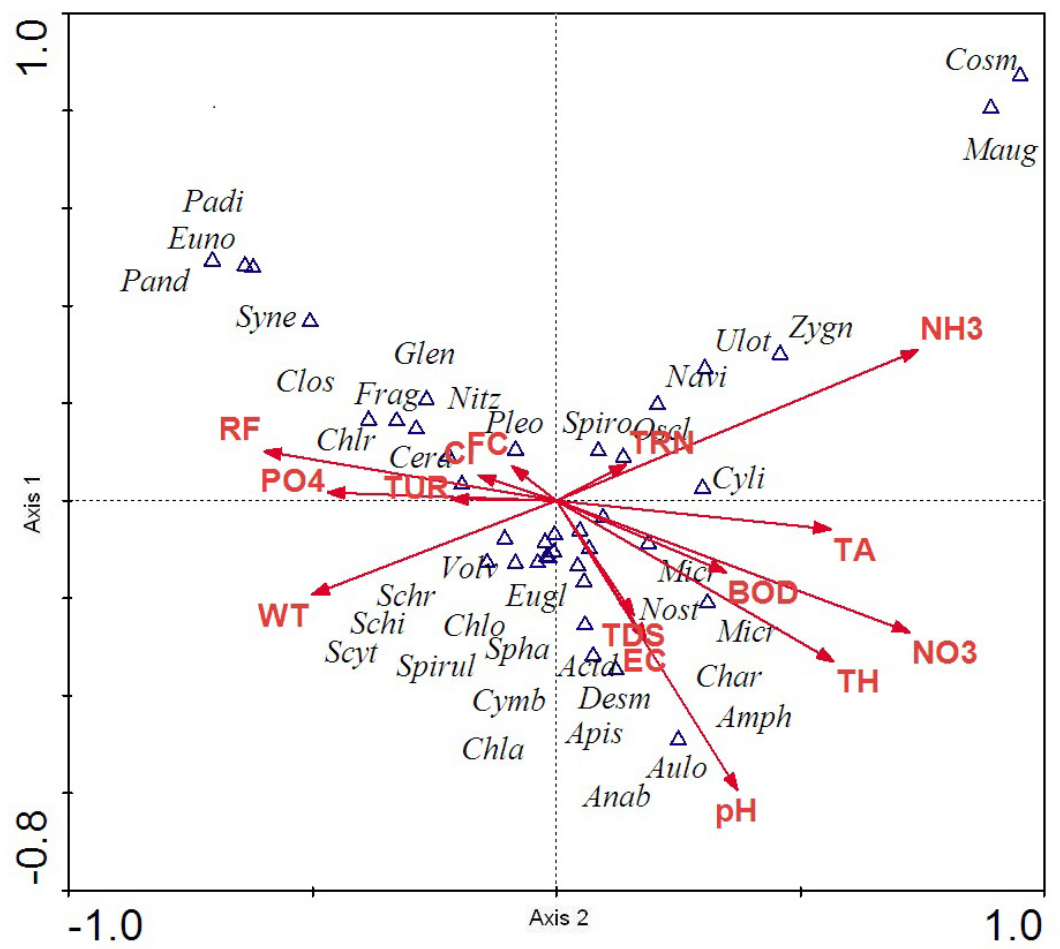

(b)

\section{Figure 4}

(a) Canorical correspondence analysis (CCA) of the phytoplankton samples collected from Chatla floodplain lake during 2006-2007 and associated environmental variables (bioplots of the species and environmental variables). (b) Canorical correspondence analysis (CCA) among the phytoplankton samples colletcted from Chatla floodplain lake during 2007-2008 and associated environmental variables (bioplots of the species and environmental variables). Abbreviations: species names were listed in Table III, $W T=$ water temperature, $T R N=$ transparency, $T U R=$ turbidity, $D O=$ dissolved oxygen, $T A=$ total alkalinity, $E C$ = electrical conductivity, TDS = total dissolved solids, $F C=$ free carbon-di-xoide, $\mathrm{Cl}=$ chloride, $B O D=$ biological oxygen demand, $\mathrm{TH}=$ total hardness, $\mathrm{NO} 3=$ nitrate, $\mathrm{PO} 4=$ phosphate, $\mathrm{NH} 3=\mathrm{am}-$ monia and $R F=$ rainfall. 


\section{Table $V$}

Summary statistics of CCA between phytoplankton species and environmental variables for first two axes in Chatla floodplain for the year 2006-2007 and 2007-2008.

\begin{tabular}{|c|c|c|c|c|}
\hline & \multicolumn{2}{|c|}{$2006-2007$} & \multicolumn{2}{|c|}{$2007-2008$} \\
\hline & Axis 1 & Axis 2 & Axis 1 & Axis 2 \\
\hline Eigenvalues & 0.188 & 0.170 & 0.405 & 0.324 \\
\hline Species-environment correlations & 0.943 & 0.943 & 0.946 & 0.899 \\
\hline Cumulative percentage variance of species data & 12.8 & 24.4 & 13.1 & 23.6 \\
\hline $\begin{array}{l}\text { Cumulative percentage variance of species-environment } \\
\text { relation }\end{array}$ & 19.6 & 37.3 & 19.2 & 34.5 \\
\hline Sum of all unconstrained eigenvalues & \multicolumn{2}{|c|}{1.468} & \multicolumn{2}{|c|}{3.087} \\
\hline Sum of all canonical eigenvalues & \multicolumn{2}{|c|}{0.961} & \multicolumn{2}{|c|}{2.111} \\
\hline Variance explained by the CCA & \multirow{2}{*}{\multicolumn{2}{|c|}{$\begin{array}{l}65.5 \% \\
24.4 \%\end{array}$}} & \multicolumn{2}{|c|}{$68.4 \%$} \\
\hline Variance explained by the first two axes & & & \multicolumn{2}{|c|}{$23.6 \%$} \\
\hline $\begin{array}{l}\text { Monte Carlo test Test of significance of all } \\
\text { canonical axes: } p \text { - values }\end{array}$ & \multicolumn{2}{|c|}{0.002} & & \\
\hline
\end{tabular}

with axis 1 . RF showed a negative relationship with axis 2 and a positive relationship with axis 1. Thus, according to CCA, during 2006-2007 phytoplankton species distribution was influenced by the environmental variables TRN, WT, TDS, RF and TUR, while in 2007-2008 it was influenced by $\mathrm{NH}_{3}, \mathrm{WT}, \mathrm{NO}_{3}, \mathrm{TH}, \mathrm{RF}$ and $\mathrm{pH}$. The influence of $\mathrm{RF}$ and $\mathrm{WT}$ in both the years confirmed that in floodplain lakes they are very important and instrumental in the plankton community distribution.

\section{CONCLUSION}

Fluctuation of phytoplankton density and community composition in different habitats indicated various niche apportionment models as well as anthropogenic influences mainly driven by rainfall.

\section{ACKNOWLEDGEMENTS}

We thank Dr. Dibyojyoti Bhattacharjee and Mr. Hemanta Saikia, Department of Business Administration, Assam University, Silchar, Assam, India, and Mr. Aribam Satish Chandra Sharma, Dept. of Ecology and Environmental Science, Assam University, Silchar, Assam, India, for their help with statistical analyses. The first author wishes to thank the University Grants Commission, New Delhi, India, for financial assistance.

\section{REFERENCES}

Akoma O.C., 2008. Phytoplankton and nutrient dynamics of a tropical estuarine system, Imo River Estuary, Nigeria. African Res. Rev., 2, 253-264.

Anand N., 1998. Indian Freshwater Microalgae. Bishen Singh Mahendra Pal Singh, Dehradun, India, $94 \mathrm{p}$.

APHA, 2005. Standard Methods for the Examination of Water and Wastewater. 21st edn. APHA, AWWA, WPCF, Washington DC, USA.

Bhuiyan J.R. and Gupta S., 2007. A comparative hydrobiological study of a few ponds of Barak Valley, Assam, and their role as sustainable water resources. J. Environ. Biol., 28, 799-802.

Borges P.A.F. and Train S., 2009. Phytoplankton diversity in the Upper Paraná River floodplain during two years of drought (2000 and 2001). Braz. J. Biol. (Suppl.), 69, 637-647.

Branes Z., Ounissi M., Sargos D. and Amblard C., 2007. Density and biomass of phytoplankton in the Oubeira Lake (North-East Algeria). J. Fisher. Intern., 2, 200-206. 
Chattopadhyay C. and Banerjee T.C., 2007. Temporal changes in environmental characteristics and diversity of net phytoplankton in a freshwater lake. Turk. J. Bot., 31, 287-296.

Chellappa N.T., Borba J.M. and Rocha O., 2008. Phytoplankton community and physical-chemical characteristics of water in the public reservoir of Cruzeta, RN, Brazil. Braz. J. Biol., 68, 477-494.

Duttagupta S., Gupta S. and Gupta A., 2004. Euglenoid blooms in the floodplain wetlands of Barak Valley, Assam, North eastern India. J. Environ. Biol., 25, 369-373.

Edmondson W.T., 1959. Freshwater Biology. 2nd edn. John Wiley and Sons, New York.

Golterman H.L., Clymo R.S. and Ohnstad M.A.M., 1978. Methods for Physical and Chemical Analysis of Freshwaters. 2nd edn. Blackwell Scientific Publishers, Oxford London.

Gupta A., Gupta S. and Michael R.G., 1994. Seasonal abundance and diet of Cloeon sp. (Ephemeroptera: Baetidae) in a northeast Indian lake. Arch. Hydrobiol., 130, 349-357.

Happey-Wood C.M., 1988. Ecology of freshwater planktonic green algae. In: Sandgren C.D. (ed.), Growth and reproductive strategies of freshwater phytoplankton. Cambridge Univ. Press, $175-226$.

Hulyal S.B. and Kaliwal B.B., 2009. Dynamics of phytoplankton in relation to physico-chemical factors of Almatti reservoir of Bijapur District, Karnataka State. Environ. Monit. Assess., 153, 45-59.

Jasprica N, Carić, M., Kršinić, F., Kapetanović, T., Batistić M. and Njire J., 2012. Planktonic diatoms and their environment in the lower Neretva River estuary (Eastern Adriatic Sea, NE Mediterranean), Nova Hedwigia, Beiheft, 141, 405-430.

Junk W.J., Bayley P.B., and Sparks R.F., 1989. The flood-pulse concept in river floodplain systems. In: Dodge D.P. (ed.), Proceeding of the International Large River Symposium Toronto, Ontario. September, 14-21, 1986. Canadian Publication of Fisheries and Aquatic Sciences -106 Department of Fisheries and Oceans, Ottawa, Ontario, Canada, 110-127.

Laskar H.S., 2012. Flood impulse, nutrient and plankton dynamics of a floodplain lake, Chatla Haor in Barak Valley of Assam, North-East India, Ph. D. Thesis, Assam University, Silchar, Assam, India.

Laskar H.S. and Gupta S., 2009. Phytoplankton diversity and dynamics of Chatla floodplain lake, Barak Valley, Assam, North Eastern India-a seasonal study. J. Environ. Biol., 30, 1007-1012.

Laskar H.S. and Gupta S., 2010. Ecology of a Marsh in Chatla floodplain, Barak Valley, North Eastern India. Eco. Env. Consv., 16, 9-15.

Laskar H.S. and Gupta S., 2011. Water quality of two small streams Jalingachhara and Baluchuri of district Cachar, Assam. Assam Univ. J. Sci. Technol., 7, 1-9.

Lund M.A. and Davies J.A., 2000. Seasonal dynamics of plankton communities and water chemistry in a eutrophic lake (Lake Monger, Western Australia): Implications for biomanipulation. Mar. Freshwater Res., 51, 321-332.

Magurran A.E., 2004. Measuring Biological Diversity. Blackwell Publishing, USA, 255 p.

Michael P., 1984. Ecological Methods for Field and Laboratory Investigations. Tata McGraw-Hill, New Delhi, $404 \mathrm{p}$.

Mitsch W.J. and Gosselink J.G., 1993. Wetlands. 2nd edn. Van Nostrand Reinhold, New York. 722 p.

Mustapha M.K., 2009. Phytoplankton assemblage of a small, shallow, tropical African reservoir. Rev. Biol. Trop., 57, 1009-1025.

Nabout J.C., Nogueira I.S. and Oliveira L.G., 2005. Phytoplankton community of floodplain lakes of the Araguaia River, Brazil in the rainy and dry seasons J. Plankton Res., Advance Access published December 1, 2005.

Nwankwo D.I., Owoseni T.I., Usilo D.A., Obinyan I., Uche A.C. and Onyema I.C., 2008. Hydrochemistry and plankton dynamics of Kuramo lagoon. Life Sci. J., 5, 83-88.

Olele N.F. and Ekelemu J.K., 2008. Physicochemical and periphyton/phytoplankton study of Onah Lake, Asaba, Nigeria. African J. Gen. Agri., 4, 183-193.

Oliveira M.D. and Calheiros D.F., 2000. Flood pulse influence on phytoplankton communities of the south Pantanal floodplain, Brazil. Hydrobiol., 427, 101-112.

Onyema I.C., 2007. The phytoplankton composition, abundance and temporal variation of a polluted estuarine Creek in Lagos, Nigeria. Turk. J. Fisher. Aqua. Sci., 7, 89-96.

Palmer M.W., 1993. Putting Things in Even Better Order: The Advantages of Canonical Correspondence Analysis, Ecology, 74, 2215-2230. 
Patterson G. and Wilson K.K., 1995. The influence of diel climatic cycle on the depth-time distribution of phytoplankton and photosynthesis in a shallow equatorial lake (Lake Baringo, Kenya). Hydrobiol., 304, 1-8.

Pielou E.C., 1984. The Interpretation of Ecological Data: A Primer on Classification and Ordination. Wiley, New York, New York, USA.

Ramesh R. and Anbu M., 1996. Chemical Methods for Environmental Analysis: Water and Sediment. Macmillan India Ltd, $161 \mathrm{p}$.

Rodrigues L. and Bicudo D.C., 2001. Similarity among periphyton algal communities in a lentic-lotic gradient of the upper Paraná river floodplain, Brazil. Revta Brasil. Bot., São Paulo, 24, 235-248.

Senthilkumar R. and Sivakumar K., 2008. Studies on phytoplankton diversity in response to abiotic factors in Veeranam Lake in the Cuddalore district of Tamil Nadu. J. Environ. Biol., 29, 747-752.

Sharma B.K., 2009. Composition, abundance and ecology of phytoplankton communities of Loktak Lake, Manipur, India. J. Threat. Taxa, 1, 401-410.

Silva I.G., Moura A.N., Dantas E.W. and Bittencourt-Oliveira M.C., 2010. Structure and dynamics of phytoplankton in an Amazon lake, Brazil. Rev. Biol. Trop., 58, 1421-1436.

Sommer U., 1989. The role of competition for resources in phytoplankton succession. In: Sommer U. (ed.), Plankton Ecology: Succession is Plankton Communities. Springer, Berlin, 57-106.

ter Braak C.J.F. and Verdonschot P.F.M. 1995. Canonical correspondence analysis and related multivariate methods in aquatic ecology. Aquat. Sci. 57, 255-289.

Thomaz S.M., Bini L.M. and Bozelli R.L., 2007. Floods increase similarity among aquatic habitats in river-floodplain systems. Hydrobiol., 579, 1-13.

Uttah E.C., Uttah C., Akpan P.A., Mikpeme E., Ogbeche J., Usip L. and Asor J., 2008. Bio-survey of Plankton as indicators of water quality for recreational activities in Calabar River, Nigeria. J. Appl. Sci. Environ. Manage., 12, 35-42.

Van den Brink F.W.B., de Leeuw J.P.H.. Van der Velde G. and Verheggen G.M. 1992-1993. Impact of hydrology on the chemistry and phytoplankton development in floodplain lakes along the Lower Rhine and Meuse. Biogeochem., 19, 103-128.

Van den Brink F.W.B., Van Katwijk M.M. and Van der Velde G., 1994. Impact of hydrology on phyto and zooplankton community composition in floodplain lakes along the Lower Rhine and Meuse. J. Plankton Res., 16, 351-373.

Vermaat J.E., 2005. Periphyton dynamics and influencing factors. In: Azim M.E., Verdegem M.C.J., Van Dam A.A. and Bederidge M.C.M. (eds.), Periphyton ecology, exploitation and management. Cambridge: CABI Publishing, 35-49.

Winkler L.W., 1888. Die Bestimmung des in Wasser gelösten Sauerstoffen. Berichte der Deutschen Chemischen Gesellschaft, 21, 2843-2855. 